\title{
Producing Liquid Organic Fertilizer from Water Hyacinth; A Case of Lake Victoria, Kenya
}

\author{
Darius O. Andika ${ }^{1 *}$, Jane Akinyi Ogada² Patrick O Hayombe ${ }^{3}$ \\ ${ }^{1}$ Jaramogi Oginga Odinga University of Science and Technology, School of Agriculture and Food Security, P. O. Box 210 -40601, \\ BONDO- KENYA \\ ${ }^{2}$ Ng'iya Girls High School, P.O Box 3-40603, NG'IYA-KENYA \\ ${ }^{3}$ Jaramogi Oginga Odinga University of Science and Technology, School of Spatial Planning and Natural Resources Management,
} P. O. Box $210-40601$, BONDO- KENYA

\begin{abstract}
Water hyacinth (Eichhornia crassipes) is a free floating freshwater plant of the family Pontederiaceae that has proven to be a significant economic and ecological burden to many sub-tropical and tropical regions of the world. Water hyacinth has infested the fresh waters of Lake Victoria threatening the ecological health of the lake, and the livelihoods of lakeshore communities that depend on it for their income. Many methods have been used to completely eradicate the weed from the lake which include; mechanical / physical removal of the hyacinth, biological control and chemical control but none of these has been able to eradicate the weed from Lake Victoria. This study therefore endeavored to determine an integration of water hyacinth management and control with community involvement in the production of liquid organic fertilizer. The specific objectives were: to determine the chemical composition of water hyacinth, to prepare liquid samples of water hyacinth in different concentrations for application in the vegetable farm and to determine the responses of crotalaria ochroleuca vegetable to water hyacinth as a liquid organic fertilizer, The study area was along the beaches of Kisumu, Homabay and Kendubay. Chemical composition of water hyacinth was determined by the use of Atomic Absorption Spectrophotometer. Prepared samples of the hyacinth were administered along with the chemical fertilizer (DAP) to crotalaria ochroleuca vegetables planted in pots and placed in a greenhouse to determine crop responses on water hyacinth applications as fertilizer. Completely Randomized Design (CRD) and a one-way ANOVA technique were used to analyze data. Water hyacinth samples from the three study areas contained significant amounts of chemical components. These were; Chlorine, Nitrogen, Phosphorous, Sulphur, Copper, Calcium, Magnesium and Lead. It was found that at 5\% level of significance, one liter water hyacinth sample significantly increased the plant height, number of leaves per plant and the leaf area, of crotalaria ochroleuca vegetable.. The study recommends that the government should encourage the production of organic fertilizer from hyacinth and involve the community in their production since these will empower the community economically and help rid the lake of the weed.
\end{abstract}

Keywords: Water hyacinth, chemical composition, Liquid fertilizer, Crotalaria Ochroleuca

\section{Introduction}

\subsection{Background of Study}

Water hyacinth (Eichhornia crassipes) is a free floating freshwater plant of the family Pontederiaceae that has proven to be a significant economic and ecological burden to many sub-tropical and tropical regions of the world [17]. Water hyacinth (Eichhornia crassipes) has been called the world's worst aquatic weed. It is a free floating water plant that is native to South America. It can vary in size from a few inches tall to over three feet. This plant has blue-green leaves, thick stalks and a showy purple or lavender flower. It thrives in tropical regions and in waters that are high in nutrients [20]. Its rate of proliferation under certain circumstances is extremely rapid and can spread to cause infestations over large areas of water causing a variety of problems. It grows in mats up to 2 meters thick which can reduce light and oxygen, change water chemistry, affect flora and fauna and cause significant increase in water loss due to evapotranspiration.

Water hyacinth originated from the Amazon Basin and was introduced into many parts of the world as an ornamental garden pond plant due to its beauty. It has proliferated in many areas and can now be found in all continents apart from Europe. It is particularly suited to tropical and sub-tropical climates and has become a problem plant in areas of Southern USA, South America, East, West and Southern Africa, South and South East Asia and Australia. Its spread throughout the world has taken place over the last 100 years or so, although the actual course of its spread is poorly documented. In the last 10 years the rapid spread of the plant in many parts of Africa is of great concern. The weed clogs up rivers, waterways and entire lakes and obstructs electricity generation, irrigation, navigation, and fishing [16]. It facilitates proliferation of diseases like bilharzia, kills aquatic life endangering the livelihoods of millions of poor people in the tropics, and is now considered a serious threat to biodiversity.

The invasion of Lake Victoria by this weed was first noticed on the Ugandan side in 1988 possibly through River Kagera. The weed has continued to invade water masses in the Lake Victoria Basin and beyond. It hampers water transport, blocks fish landing sites and impedes access by humans and livestock besides harboring disease vectors. It is thus a threat to the environment and economy of the region (Jumuiya, 2011). This noxious weed was unintentionally introduced into Lake Victoria, the world's second-largest freshwater lake, probably during the 1950 s. The weed now covers over 40,000 hectares of the lake and its watershed. 


\section{International Journal of Science and Research (IJSR) \\ ISSN (Online): 2319-7064}

Index Copernicus Value (2013): 6.14 | Impact Factor (2014): 5.611

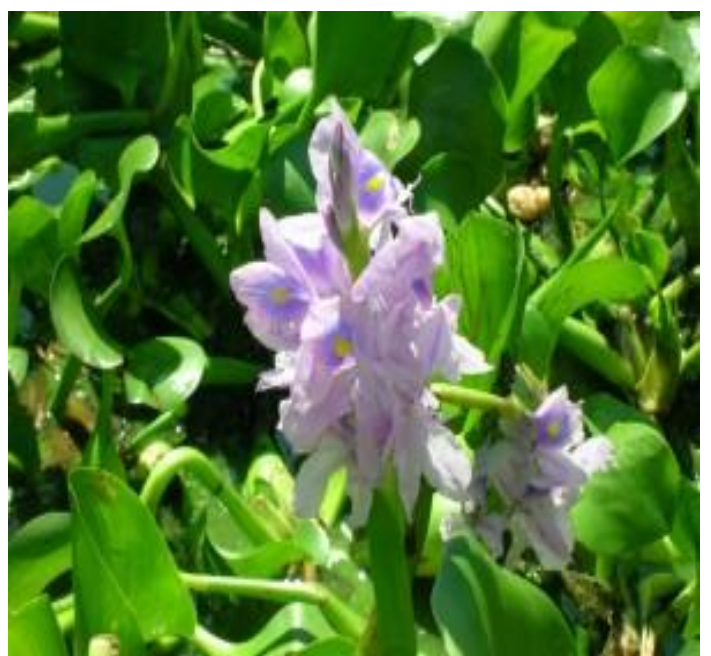

Plate 1: A flowering water hyacinth; photo taken in Dunga beach, Kisumu

Source; Field studies at the beaches in Lake Victoria

This infestation threatens both the ecological health of the lake, and the livelihoods of lakeshore communities that depend for their income on lacustrine resources such as fish. Large-scale business and trade was also negatively affected when the port areas became inaccessible and water intake pipes for dams were blocked. Some port towns on the lake have recorded as much as a 70 percent decline in economic activity because the hyacinth has choked landing facilities and fishing grounds. Such occurrences and even the possibility of worse economic effects resulting from obstruction of navigation of boats and fishing and blockage of irrigation and drainage systems could worsen the economy of Kisumu, which has a poverty index of $68 \%$ [21].

Efforts have been made by various countries to control the water hyacinth. These methods range from mechanical or physical removal of the hyacinth, biological control to chemical use, but no method has completely succeeded in removing the weed. In Kenya, efforts to control water hyacinth in Lake Victoria during the early 1990 were of limited success and were primarily directed at manual removal and conducting public awareness exercises. In the mid-1990s management to combat water hyacinth increased with efforts such as the Lake Victoria Environmental Management Program (LVEMP-1) and US Agency for International Development (USAID), through development funding for coordination [26]. Control actions included biocontrol using weevils, mechanical control using large harvesting and chopping boats known as the swamp devils [10]. Mechanical control options include harvesting plants and in-situ cutting. In-situ cutting, where plants are left to decay and decompose in the water can decrease dissolved oxygen and alter trophic structure resulting in changes in nutrient and carbon balances [13]. Low dissolved oxygen catalyzes the release of phosphorous from the sediment and an increase in phosphorous often leads to a subsequent increase in water hyacinth or algae blooms [35], [4]. Herbicides are less selective than mechanical or manual approaches and can kill non target algae and microphytes resulting in far reaching ecological impacts [2]; Ramirez, Roja, \& Alcocer, 2007). The herbicide is sprayed directly on to the leaves of water hyacinth to avoid killing algae in the water column.

Biological control has not been successful either in reducing water hyacinth plant in Lake Victoria Kenya. The use of the Neochetina weevils requires a prior use of mechanical and chemical control for it to be effective. This makes it very expensive and time consuming. This study advocates for an integrated water hyacinth management in the production of liquid organic fertilizer and handicrafts. The initial methods used have been those that destroy the weed and not to utilize it for economic use. Water hyacinth has been used both as fertilizer and in the production of handicrafts in various countries like India and Bangladesh. This study would like to advocate for the production of fertilizer and handicrafts from the water hyacinth with a view to involve the community living along the shores of Lake Victoria and depend on the lake for their livelihood. Introducing projects that involve the production of liquid fertilizer and handicrafts from the water hyacinth would go a long way in creating jobs for the youth and the women in the community and thereby improve their livelihood.

\subsection{Specific Objectives}

The specific objectives of the study were to;

1)Determine the chemical composition of water hyacinth from different beach fronts of the lake

2)Prepare liquid samples of water hyacinth in specific concentrations for application in the vegetable farm

3)Determine the responses of crotalaria ochroleuca vegetable to water hyacinth liquid organic fertilizer.

\section{Literature Review}

\subsection{Invasion of the water hyacinth}

Water hyacinth (Eichornnia crassipes) is a true water plant and floats by means of spongy petioles. It is the most prolific and spectacular plant of all the aquatic plants. It was first introduced into the United States from Venezuela and exhibited at the New Orleans cotton exposition in 1884 [7]. Garden lovers sought this botanical curiosity and set them in pools and ponds. Very soon the plants escaped their garden bounds and infested the streams and bays with the result that for the past forty years many thousands of pounds have been spent in trying to keep in bounds this navigational nuisance. Dearl et al, 2004, point out that the plant propagates itself from tiny root fragments which break off from the large plants and quickly develop leaf stalks and broad green leaves. Runners also grow along the water surfaces from the base of the petioles, resulting in a rapid spread of vegetative reproduction.

Water hyacinth has invaded fresh water systems in over 50 countries on five continents. It is especially pervasive throughout Southeast Asia, the Southern United States, Central, East and Western Africa and Central America [24], [26]. It is prevalent in tropical and subtropical water bodies where nutrient levels are often high due to agricultural runoff, deforestation and insufficient waste water treatment. In recent 


\section{International Journal of Science and Research (IJSR) \\ ISSN (Online): 2319-7064}

Index Copernicus Value (2013): 6.14 | Impact Factor (2014): 5.611

years, water hyacinth has spread faster, and the most serious infestation is in Lake Victoria. It is unknown how water hyacinth first entered Lake Victoria but the resulting infestation has become a massive problem over the last two decades. Itwas first reported in Ugandan waters in 1988 and since then, the infestation has spread across the lake from the likely source, the Kagera River, all the way to the Kenyan border [18].

\subsection{Chemical composition of Water Hyacinth}

Fresh plant contains: $95.5 \%$ moisture, $0.04 \% \mathrm{~N}, 1.0 \%$ ash, $0.06 \% \mathrm{P}_{2} \mathrm{O}_{5}, 0.20 \% \mathrm{~K}_{2} \mathrm{O}, 3.5 \%$ organic matter. On a zeromoisture basis, it is $75.8 \%$ organic matter, $1.5 \% \mathrm{~N}$, and $24.2 \%$ ash. The ash contains $28.7 \% \mathrm{~K}_{2} \mathrm{O}, 1.8 \% \mathrm{Na}_{2} \mathrm{O}, 12.8 \%$ $\mathrm{CaO}, 21.0 \% \mathrm{Cl}$, and $7.0 \% \mathrm{P}_{2} \mathrm{O}_{5}$. The crude protein $(\mathrm{CP})$ contains, per $100 \mathrm{~g}, 0.72 \mathrm{~g}$ methionine, $4.72 \mathrm{~g}$ phenylalanine, $4.32 \mathrm{~g}$ threonine, $5.34 \mathrm{~g}$ lysine, $4.32 \mathrm{~g}$ isoleucine, $0.27 \mathrm{~g}$ valine, and $7.2 \mathrm{~g}$ leucine [28].

In a laboratory based experiment designed to mimic nutrient conditions of Lake Chivero, Uganda, Rommens et al (2003) tested water hyacinth's uptake capacity to absorb nitrates $\left(\mathrm{NO}_{3}{ }^{-}\right)$, ammonium $\left(\mathrm{NH}_{4}^{+}\right)$and phosphates $\left(\mathrm{PO}_{4}{ }^{3-}\right)$ from a water column. The average water hyacinth plant absorbed $2.36 \mathrm{mg}$ of ammonium, $1.13 \mathrm{mg}$ of nitrate and $0.39 \mathrm{mg}$ of phosphates per kilogram of water hyacinth (wet weight) each hour. These results could be used to estimate potential nutrient response in systems where water hyacinth has been introduced or where it has been removed. Water hyacinth's uptake capacity has been validated in several field studies as well. It has a high nutrient uptake rate compared to other macrophytes [37]. It therefore has the potential to significantly reduce nutrient concentrations in the water body depending on the extent of cover and density (Pinto-Coelho \& Greco, 1999). Overall nutrient uptake is thought to vary by season, with greater uptake in the summer when temperatures are higher and more favorable for plant growth [39]. Ogulande, (2012), confirmed that the water hyacinth contained high levels of heavy metals, ranging from $12.04 \%$ in the leaf blade to $19.03 \%$ in the roots and $16.10 \%$ for petiole. This suggests that the plant is rich in minerals. Water hyacinth has the ability to absorb nutrients from the water as mentioned earlier and this ability increases with increase in temperature. The temperatures along the Lake Victoria region are high enough to allow for the sufficient uptake of the nutrients and thus the need to verify this in this study in order to determine the chemical components that the water hyacinth in this region has and whether these components are suitable for fertilizer production.

\subsection{Water hyacinth control and management}

Water hyacinth is extremely difficult to eradicate once established. The goal of most management efforts is to minimize economic costs and ecological change. Recent literature on management of water hyacinth focuses on techniques to remove the weed, however, little has been done to assess the full extent of ecological changes that may occur in response to the establishment of this weed. Efforts have been made by various countries to control or manage the water hyacinth. These methods range from mechanical or physical removal of the hyacinth, biological control to chemical use, but no method has completely succeeded in controlling the menace. There are three main methods of control of this notorious weed namely physical, chemical and biological. Physical control involves both manual and mechanical removal, a tedious and time-consuming exercise, involving the use of huge and very expensive machinery and human labor (Jumuiya, 2011).

Water hyacinth problem in Kenya and in Lake Victoria in particular has been mitigated by integrated weed management (IWM) strategies with emphasis on biological control program which were initiated in 1995 under the Lake Victoria Management Programme (LVEMP), which is a comprehensive regional level environmental programme. Kenya has integrated biological control, manual removal of water hyacinth at strategic sites in collaboration with the local communities, quarantine regulations and management of nutrient influx into rivers, ponds and lakes to attain sustainable management of water hyacinth.

Water hyacinth infestation in Lake Victoria gradually increased to a maximum of 6000 hectares (1998) and declined to current levels of an estimated 400 hectares (2001). The efforts in the control of this weed have been mainly through KARI using biological control agents (weevils). Other methods used in combating this weed include Aquatic Vegetation Cutters (AVCs) by an American Company Aquarius Systems, meant to shred 1500 hectares and use of manual removal using hand tools/implements (Noah \& Gerald, 2005)

\subsection{Socio-economic uses of water hyacinth}

In Nigeria, water hyacinth has over the years been used as food for domestic animals more so goats. Baldwin, Gentges \& Bagnal (2004), establishes that water hyacinth (E. crassipes) was collected from River Majidun in Ikorodu Local Government, Lagos State of Nigeria. The stalks and leaves were chopped and sun dried for about 5 days at an environmental temperature $\left(22.8-33.8^{\circ} \mathrm{C}\right)$ and relative humidity $(54.0-96.0 \%)$ and distributed to farmers as animal feed in a government project aimed at fighting effect of climate change due to drought. Baldwin et al, (2004) establish that water hyacinth not only managed to sustain the domestic animals during the drought period but was also very rich in minerals such as magnesium and sodium. On noticing this, the private sector and other individuals started setting up structures for transporting and processing the plant to farmers at a fee in the state of Lagos.

As a fertilizer, water hyacinth can be used on the land either as a green manure or as compost. As a green manure it can be either ploughed into the ground or used as mulch. The plant is ideal for composting. After removing the plant from the water it can be left to dry for a few days before being mixed with ash, soil and some animal manure. Microbial decomposition breaks down the fats, lipids, proteins, sugars and starches. The mixture can be left in piles to compost; the warmer climate of tropical countries accelerates the process and produces rich pathogen free compost which can be applied directly to the soil. The compost increases soil fertility and

\section{Volume 5 Issue 2, February 2016}




\section{International Journal of Science and Research (IJSR) \\ ISSN (Online): 2319-7064}

Index Copernicus Value (2013): 6.14 | Impact Factor (2014): 5.611

crop yield and generally improves the quality of the soil [14]. Gourab and Soumen (2008) confirmed, that organic manure gives far more better result than chemical fertilizer and it costs nothing, but only labor. They further concluded that chopped stalk and leaves of water hyacinth with cow dung in $8: 1$ ratio (by volume), with little bit of curd may turn the water hyacinth a good quality compost with high nutrient value within a very short period of time [12] .Water Hyacinth liquid manure has significantly high $\mathrm{N}(3.72 \%)$ and $\mathrm{P}(2.86 \%)$ contents indicating its suitability as a macronutrient fertilizer [42].

Water hyacinth is a free floating plant and draws all its nutrients directly from water. Currents and wind help in its distribution and dispersal. It comprises $95 \%$ water and 5\% per cent dry matter of which $50 \%$ is silica, $30 \%$ potassium, $15 \%$ nitrogen and $5 \%$ protein (Makhanu, 1997). It has been known to thrive well in nutrient-enriched fresh waters in tropical climatic zones. For this purpose it has been used in wastewater treatment facilities. Water hyacinth (Eichornnia crassipes) has a high capacity for the uptake of heavy metals, including $\mathrm{Cd}, \mathrm{Cr}, \mathrm{Co}, \mathrm{Ni}, \mathrm{Pb}$ and $\mathrm{Hg}$ which could make it suitable for bio cleaning of the industrial waste water [44]. In addition to heavy metals, water hyacinth can remove other toxins, such as cyanide, which is environmentally beneficial in areas that have endured gold mining operations [9]. It removes arsenic from contaminated drinking water. It is useful in removing arsenic from tube well water in Bangladesh [31].

Water hyacinth is an economically viable plant which has been used by a number of countries. Commercialization of these uses and the involvement of communities in the process have not been explored especially in the East African countries. There is need to explore more of its uses and to commercialize those that already exist in order to maximize the use of water hyacinth in Lake Victoria to the benefit of the local communities living along the lake shores. Its use in the production of liquid fertilizer has not been exploited so far by most countries. This study intended to explore this use and to determine the viability of using the weed as a fertilizer without necessarily composting it.

\subsection{Responses of crops to water hyacinth liquid organic fertilizer}

In an experiment conducted by Ogulande, 2008, to test the performance of water hyacinth, the $\mathrm{C} / \mathrm{N}$ ratio of water hyacinth indicates that formation of organic matter consists of better humid fertilizer. The root extract of the plant was reported to aid crop reduction in a number of economic species such as Corchorus capsularies. This was confirmed by Oso (1988) by the production of liquid fertilizer from water hyacinth which enhanced the growth of okra and Amaranthus seedlings when applied as a top dressing [32].The study of water hyacinth as bio fertilizer revealed that the incorporation of water hyacinth into soil crop system increased the performance yield of the crop plant Brassica juncea [23]. The study focused on determining the responses of crotalaria ochroleuca vegetable on water hyacinth liquid fertilizer.

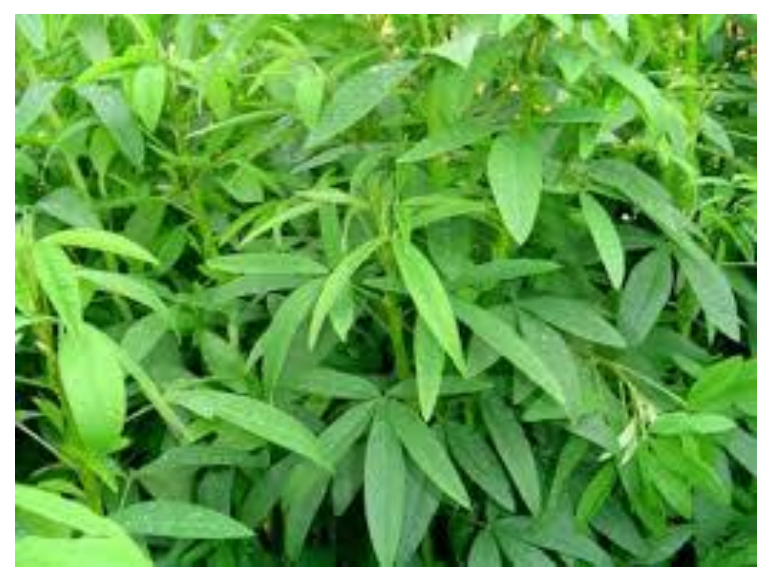

Plate 2: Crotalaria ochroleuca vegetable Source; Field studies, 2015

Plants in the crotalaria genus belong to the family Fabaceae / Leguminaceae. The genus crotalaria includes about 500 species of herbs and shrubs of which 400 species can be found in Africa [34].The two African species used as a vegetable are Crotalaria ochroleuca and Crotalaria brevidens. The former has a mild taste whereas the latter has a bitter taste, but both species are commonly called rattle pod, rattle box, sun hemp or slender leaf. Crotalaria ochroleuca has bright green leaves, and grows to a height of $250 \mathrm{~cm}$. The flowers are pale yellow or creamish in colour and the seeds are normally but not always light yellow and the pods are wider in diameter and big. Crotalaria brevidens has bluish green leaves, and grows to a height of $210 \mathrm{~cm}$ and has bright yellow flowers and the seed color normally contains anthocyanin and is light brown in color and the pods are small and narrow in shape [1]. The main distinguishing features of the two species are the taste and pod size. The center of diversity of both species is believed to be Africa and the two crotalaria vegetable species are commonly cultivated and consumed throughout East Africa and to a limited extent in WestAfrica

\section{Methodology}

\subsection{Research Design}

This study involved experimental design where an experimental design is a plan for designing units to treatment levels and the statistical analysis associated with the plan [22]. The experiments were conducted including laboratory analysis and greenhouse experiments to determine crop responses to water hyacinth liquid fertilizer.

\section{Chemical Analysis}

Water hyacinth samples were collected and decomposed for 15 days. 


\section{International Journal of Science and Research (IJSR) \\ ISSN (Online): 2319-7064}

Index Copernicus Value (2013): 6.14 | Impact Factor (2014): 5.611

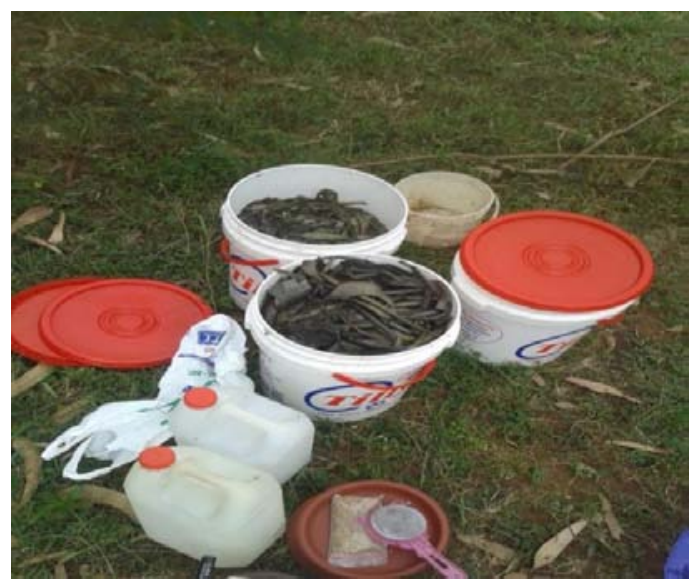

Plate 3: Decomposed water hyacnth after 15 days Source; Field studies at the school of Agriculture, JOOUST

Liquid samples obtained from the decomposed water hyacinth, were then filtered and analyzed to identify the chemical composition of the hyacinth. Quantitative analyses were done by use of an Atomic Absorption Spectrophotometer (AAS) to determine the concentrations of the metal ions; calcium, lead, copper and magnesium and the nonmetallic ions of Chloride, Sulphate, Phosphate and Nitrate ions.

Determination of responses of crotalaria ochroleuca (slender leaf) vegetable to water hyacinth fertilizer as compared to chemical fertilizer

The second objective involved the determination of responses of chrotalaria ochroleuca (slender leaf) vegetable to the water hyacinth fertilizer as compared to the chemical fertilizer (DAP). Completely Randomized Design (CRD) was used in this case because it is simple and randomizes the differences among the sample items [19]. The vegetable was planted in pots and various levels of water hyacinth treatments were administered along with DAP chemical fertilizer.

\section{Treatment application}

Five treatments were formulated and these were replicated three times giving a total of fifteen experimental units. Replication was done to increase the accuracy of the experiment [19]. Each pot had a surface area of $0.11665 \mathrm{~m}^{2}$. This meant that the amount of DAP to be applied per pot had to be calculated from the standard $200 \mathrm{~kg} / \mathrm{ha}$ and this gave $2.33 \mathrm{~g} /$ pot.

Based on the chemical analysis results, the average amount of nitrates in the water hyacinth liquid was $1.4 \mathrm{mg} /$ liter and that of phosphorous was $41.75 \mathrm{mg} /$ liter. An equivalent amount of DAP per pot was calculated with respect to the standard $46 \%$ Nitrogen that the DAP would provide and the calculation gave $0,00304 \mathrm{~g} / \mathrm{lit}$

Table 3.1: Treatment applications used in the experiment

\begin{tabular}{|c|c|c|}
\hline Treatment & Type & Amount \\
\hline 1 & DAP & $0.0034 \mathrm{~g}$ \\
\hline 2 & water hyacinth & 1.0 liters \\
\hline 3 & water hyacinth & 0.5 liters \\
\hline 4 & water hyacinth & 1.5 liters \\
\hline 5 & control(no fertilizer) & Nil \\
\hline
\end{tabular}

The three treatments of Water hyacinth liquid were administered 3 days after germination, at intervals of two days for a period of two weeks which gave a total of five applications for each treatment. To ensure that the specified volumes of the treatments were finally applied by the end of the five days, the following volumes of each treatment were applied during each interval: $200 \mathrm{~cm}^{3}$ of treatment $2,100 \mathrm{~cm}^{3}$ of treatment 3 , and $300 \mathrm{~cm}^{3}$ of treatment 4 .

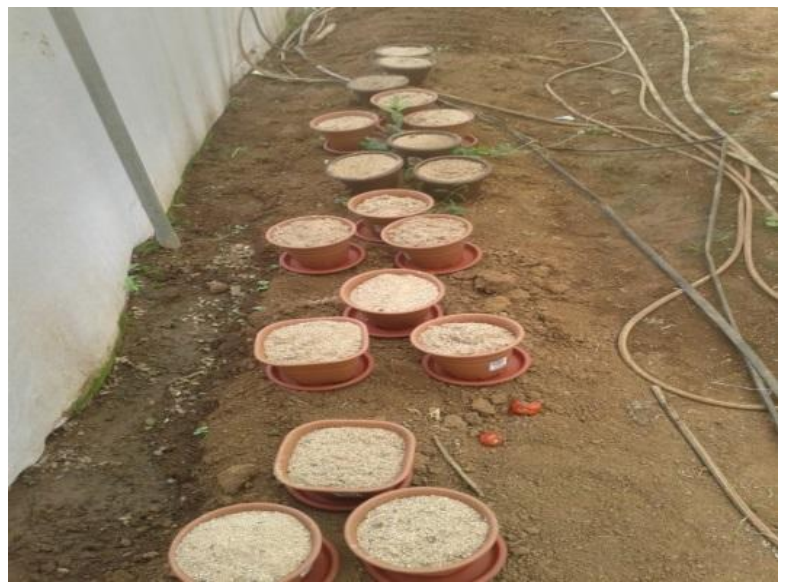

Plate 4: Experimental pots containing sand in the greenhouse Source; Field studies at the school of Agriculture, JOOUST

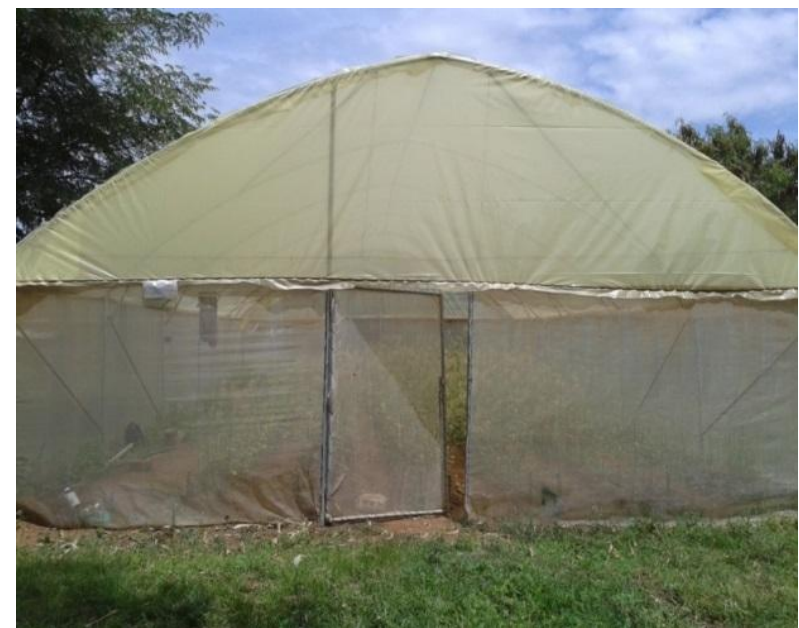

Plate 5: Greenhouse at Jaramogi Oginga Odinga University Source; Field studies at school of Agriculture, JOOUST

\subsection{Data Analysis}

One-way ANOVA technique and the f-test was used to analyse the primary data derived from the experiment on the responses of crotalaria ochroleuca vegetables to water hyacinth as an organic fertilizer. The hypothesis of the study that states that there is no any significant difference in the responses of crotalaria ochroleuca vegetables to water hyacinth liquid organic fertilizer as compared to the chemical fertilizers (DAP) was then tested. 


\section{International Journal of Science and Research (IJSR) \\ ISSN (Online): 2319-7064}

Index Copernicus Value (2013): 6.14 | Impact Factor (2014): 5.611

\section{Results and Discussions}

\subsection{Chemical Composition}

Table 4.2: Summary of Chemical Composition of Water Hyacinth

\begin{tabular}{|c|c|c|c|c|}
\hline \multicolumn{7}{|c|}{ Concentration in m//lit } \\
\hline Component & Hippo point & Dunga & Usoma & Usare \\
\hline Nitrates & 1.66 & 2.06 & 1.36 & 0.55 \\
\hline Phosphates & 30 & 41 & 38 & 58 \\
\hline Chloride & 44 & 14.5 & 14.5 & 26 \\
\hline Calcium & 310 & 250 & 100 & 125 \\
\hline Magnesium & 110 & 220 & 80 & 65 \\
\hline Lead & 0.83 & 0.92 & 0.38 & 0.72 \\
\hline Copper & 0.09 & 1.21 & 0.46 & 0.69 \\
\hline Sulphates & 56 & 52 & 36 & 42 \\
\hline
\end{tabular}

Source; Field studies in Kisumu region, 2015

The results show that calcium, magnesium, lead, chloride, phosphates and sulphates had high concentrations while those of copper and nitrates were low in all the four beaches of Kisumu region. This could be because of increased industrial and house hold activities due to increasing population, increasing pollution into the lake.

\subsection{Responses of crotalaria ochroleuca vegetable on water hyacinth as an organic fertilizer}

To establish the performance of hyacinth as an organic fertilizer an experiment was performed in JaramogiOgingaOdinga University, School of Agriculture and Food Security. The performance of hyacinth as an organic fertilizer was examined with focus on crotalaria ochroleuca vegetables. The indicators of performance were plant height, leaf number, stem diameter, leaf area and branch number. The collected data was summarized in tables according to the days they were collected. Analysis of data was then done and summarized in the tables below. The means of the various indicators were calculated and the specific ANOVA tests were determined.

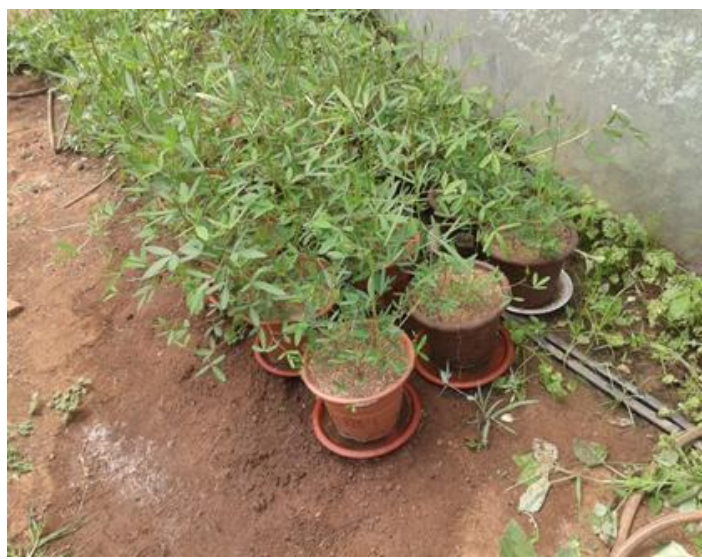

Plate 6: Crotalaria ochroleuca plants after seven weeks

\section{Plant Height}

The plant height increased consistently from week 1 to week 3 for all the treatments as indicated in table 6.1 above. However treatment 2 had the highest increase throughout the three weeks with week 3 having the highest height of 12.5 $\mathrm{cm}$. Treatment 2 was one liter of water hyacinth which proved to be more effective than all the other treatments.

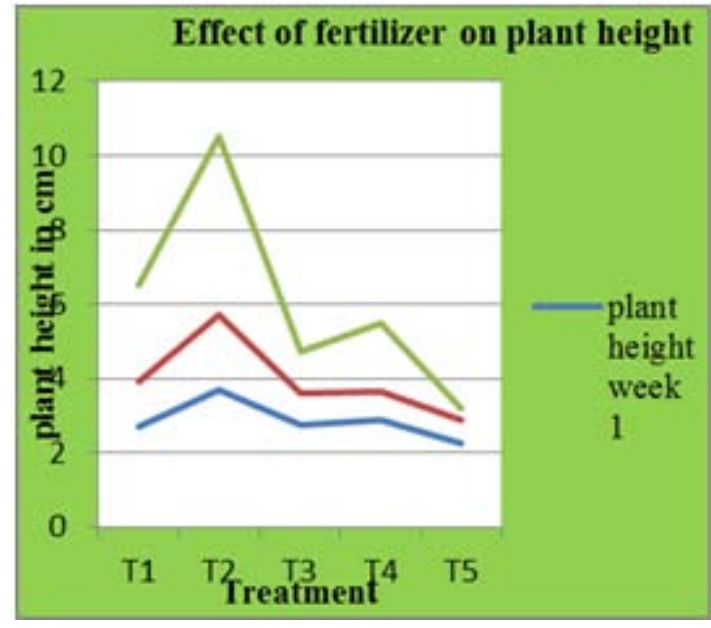

Figure 4.1

\section{Responses of crotalaria ochroleuca on fertilizer}

Plant height of crotalaria ochroleuca in week one, was low and averaged at about $2.5 \mathrm{~cm}$ for all the treatments except treatment 2 which had approximately $4 \mathrm{~cm}$. The plant heights were highest in week three with treatment 2 having the highest value of above $10 \mathrm{~cm}$. Treatment 2 was one liter water hyacinth and because it gave the best results in improving the plant height, it showed it had the appropriate concentrations of the plant nutrients that were necessary for plant growth.

An ANOVA test was conducted to check whether the influence of hyacinth fertilizer on plant height was statistically significant or not at $95 \%$ confidence level.

Water hyacinth liquid fertilizer significantly $(\mathrm{P} \leq 0.05)$ increased the plant height of crotalaria ochroleuca vegetable than the DAP and the other treatments (Appendix 6). Application of liquid water hyacinth statistically led to improvement of the plant height. This result is in line with the findings of Sanni and Adesina (2012) where they confirmed that increase in plant growth and yield as a result of application of water hyacinth manure is expected in that manure contained and released considerable amount of $\mathrm{N}$ and $\mathrm{Mg}$ for plant use during the process of mineralization [40]. These minerals are essential for formation of chlorophyll for photosynthesis in plants.

\section{Stem Diameter}

There was no consistency in the stem diameter of the plants throughout the three weeks for all the treatments. This could have been caused by many factors including the insufficiency of the required nutrients for stem diameter growth. 


\section{International Journal of Science and Research (IJSR) \\ ISSN (Online): 2319-7064}

Index Copernicus Value (2013): 6.14 | Impact Factor (2014): 5.611

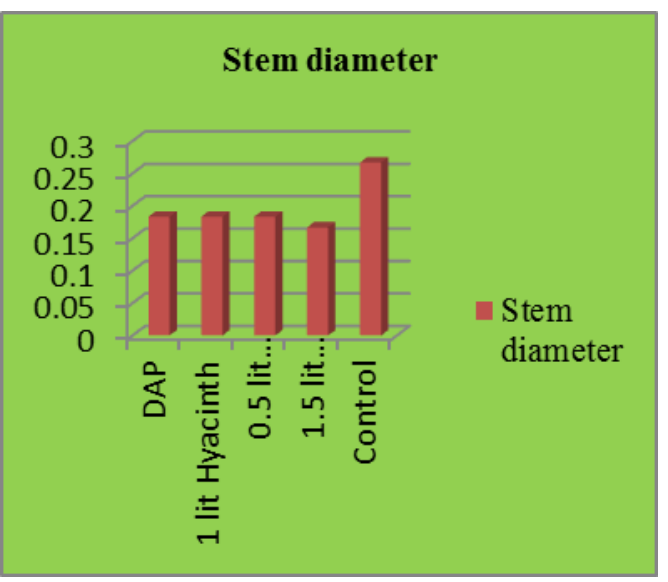

Figure 4 .2: Responses of crotalaria ochroleuca stem diameter to fertilizer

The three concentrations of water hyacinth and DAP had almost the same effect on the stem diameter of crotalaria ochroleuca since it averaged at $0.1833 \mathrm{~mm}$. The control on the other hand had a higher value of $0.2635 \mathrm{~mm}$. This showed water hyacinth fertilizer had no significant effect on stem diameter of crotalaria ochroleuca plant. This could have been caused by the variation in the concentrations of plant nutrients in the amounts of water hyacinth that were administered to the plants. The required concentrations for stem development were not achieved within the period of the experiment.

Water hyacinth liquid fertilizer had no significant $(\mathrm{P} \geq 0.05)$ effect on the stem diameter of crotalaria ochroleuca vegetable as compared to DAP and the other treatments (Appendix 6). This therefore showed that the hyacinth fertilizer had no significant effect on the stem diameter as compared to the chemical fertilizer. As Sanni and Adesina (2012), found out, the variation in growth parameters due to nutrient sources was considered to be due to variation in the availability of major nutrients. There are specific nutrients required at specific concentrations for the specified growth parameters. This therefore means that for the stem diameter, the concentrations for the nutrients that encourage stem growth were not to the required concentrations as at the time of data collection.

\section{Leaf Area}

The leaf area of crotalaria ocroleuca plant increased consistently throughout the three weeks in all the treatments with treatment 2 having the highest increase. All the hyacinth concentrations had an increase in the leaf area than DAP confirming further that water hyacinth is a better fertilizer than DAP.

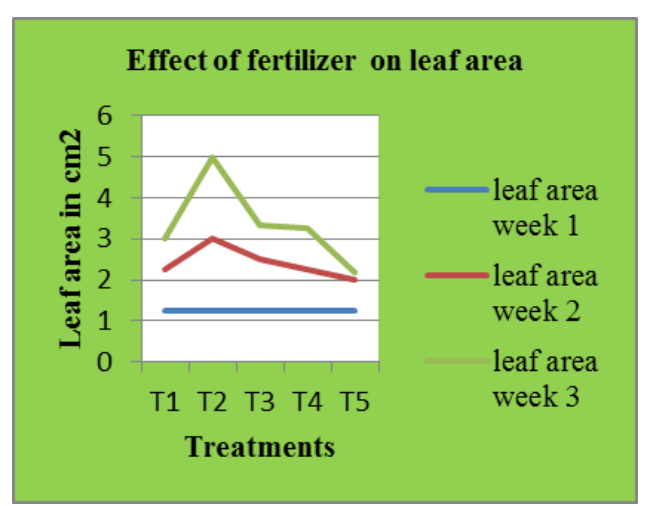

Figure 4.3: Responses of crotalaria ochroleuca leaf area on fertilizer

The leaf area of crotalaria ochroleuca averaged at approximately $1.3 \mathrm{~cm}^{2}$ in the first week but increased greatly in the third week with treatment 2 having the greatest increase of $5 \mathrm{~cm}^{2}$ (Fig 4.7). This further confirms that that treatment 2 had the required concentrations of the plant nutrients. The mean leaf area was calculated after the three weeks of data collection and the results show that the plants with one liter application of water hyacinth had a larger leaf area as compared to the other treatments.

Water hyacinth liquid fertilizer had significant $(\mathrm{P} \leq 0.05)$ effect on the leaf area of crotalaria ochroleuca vegetables than the DAP and the other treatments (Appendix 6). This showed that, at 5\% level of significance, the application of hyacinth fertilizer had a significant effect compared to chemical fertilizer in increasing the leaf area proving further that it is a better fertilizer than the chemical one. This result is in line with the findings of Simbarashe et al, that water Hyacinth liquid manure has significantly high $\mathrm{N}(3.72 \%)$ and $\mathrm{P}(2.86 \%)$ contents indicating its suitability as a macronutrient fertilizer [41]. Presence of nitrogen and phosphorus enhances the formation of chlorophyll which increases the leaf area.

\section{Leaf and Branch Number}

The number of branches were observed in the second and third week of data collection (Table 4.6 ). On the other hand, the number of leaves increased consistently from week 1 to week 3 with treatment 2 having the highest increase (Table 4.7)

\section{Leaf number}

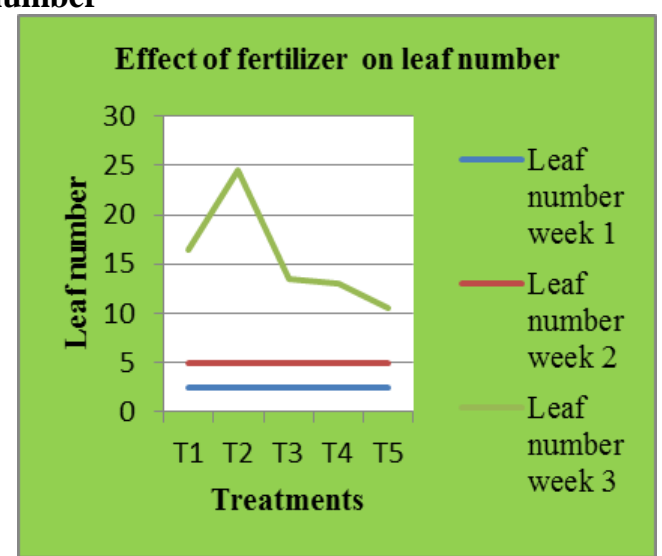

Figure 4.4: Responses of crotalaria ochroleuca leaf number to fertilizer 


\section{International Journal of Science and Research (IJSR) \\ ISSN (Online): 2319-7064}

Index Copernicus Value (2013): 6.14 | Impact Factor (2014): 5.611

Number of leaves per plant remained constant for the first two weeks for all the treatments. However in week three, there was a big change in the number of leaves with treatment 2 having the highest increase of about 25 leaves. This confirmed further that treatment 2 had the sufficient concentrations of plant nutrients for plant growth which were greatly realized in week three. The results show that the average number of leaves per plant increased with application of the hyacinth fertilizer on the vegetable. The study further conducted an ANOVA test to test the hypothesis that there is no significant difference in the performance of water hyacinth as a fertilizer as compared to the chemical one.

Water hyacinth liquid fertilizer significantly $(\mathrm{P} \leq 0.05)$ increased number of leaves of crotalaria ochroleuca vegetable than DAP and the other treatments, showing that at $5 \%$ level of significance, application of hyacinth fertilizer led to statistically significant improvements in the number of leaves per plant. Water hyacinth had no significant $(\mathrm{P} \geq 0.05)$ difference in increasing the number of branches per plant as compared to the DAP and other treatments.

The study found that at 5\% level of significance, fertilizer made from hyacinth significantly performed well in terms of improving plant height, increasing the leaf area and increasing the number of leaves per plant. The null hypothesis that states that, there is no significant difference in the responses of crotalaria ochroleuca to water hyacinth organic fertilizer as compared to the chemical fertilizer is therefore rejected.

This was confirmed by Oso (1988) by the production of liquid fertilizer from water hyacinth which enhanced the growth of okra and Amaranthus seedlings when applied as a top dressing [32].The study of water hyacinth as bio fertilizer revealed that the incorporation of water hyacinth into soil crop system increased the performance yield of the crop plant Brassica juncea [23].

Gourab and Soumen, 2008 confirmed, that organic manure gives far more better result than chemical fertilizer and it costs nothing, but only labour. They further concluded that chopped stalk \& leaves of water hyacinth with cow dung in $8: 1$ ratio (by volume), with little bit of curd may turn the water hyacinth a good quality compost with high nutrient value within a very short period of time [12]. Water Hyacinth liquid manure had significantly high $\mathrm{N}(3.72 \%)$ and $\mathrm{P}$ $(2.86 \%)$ contents indicating its suitability as a macronutrient fertilizer [42].

Organic farming is a standardized alternative agricultural paradigm that relies on ecological processes, biodiversity and cycles adapted to local conditions with the aim of sustaining the health of soils, ecosystems and people [15]. Organic fertilizers are soil amendments containing the minimum contents of, at the minimum, nitrogen, phosphate and potash (NPK) that is derived solely from the vestiges or derivatives of an organism [5]. Liquid organic fertilizers have largely remained in the background of mainstream scientific literature and what little knowledge exists about them is mainly confined to biodynamic farming literature [18].

\section{Conclusions}

Chemical fertilizer which is readily available has been the alternative source of improving soil condition in the lake region [33]. According to Omwoyo, (2012) repeated use of chemical fertilizer in the catchment areas and around Lake Victoria has led to eutrophication of the lake waters causing the temperature to rise in the process affecting most freshwater animals. Omwoyo (2012) further states that, eutrophication also encourages large volumes of algae and other biomass such as water hyacinth to flourish and in the process consume all the oxygen in the water causing ecological and socio- economic problems, death of fish and other creatures in the water ecosystem. Water hyacinth has been used as green manure and compost in various countries as stated by Henrylito and Tacio, 2001. But its use as liquid fertilizer has not been exploited in Kenya. This study confirms that liquid water hyacinth is a better fertilizer since it improved the crop yield better than the chemical fertilizers. This is in line with the findings by Simbarashe, Benard \& Precious (2013) that confirmed that liquid water hyacinth contained significantly high $\mathrm{N}(3.72 \%)$ and $\mathrm{P}(2.86 \%)$ contents indicating its suitability as a macronutrient fertilizer. There is therefore an urgent need to revolutionize the agricultural systems by using alternative ecologically friendly and sustainable source of soil nutrients.

\section{Recommendations}

The study recommends that the government should encourage the production of liquid organic fertilizer from hyacinth and involve the community in its production. This is because it is a better fertilizer than the chemically produced ones and it will not only empower the community economically but will help rid the lake of the menace of water hyacinth. The study suggests that a manufacturing plant be established in Kisumu for the production of liquid organic fertilizer from water hyacinth. The industry is believed that it will be able to involve the community in its functions especially in the harvesting of the weed from the lake there by creating employment for the locals. There is a huge amount of money used by the government of Kenya in importing synthetic fertilizer for agricultural activities. These chemical fertilizers are also a source of reduced soil fertility and increased pollution effects in the water bodies causing harm to the aquatic life and growth of algae blooms. Therefore the establishment of an industry that would produce liquid organic fertilizer from water hyacinth would go a long way in improving soil fertility and subsequently crop yield in the country. Food security and alleviation of poverty and hunger will be achieved (MDG 1).

\section{References}

[1] Abukutsa-Onyango M., (2004)Crotalaria brevidens, Plant Resources of Tropical Africa, Vegetables. PROTA Foundation, Wageningen, Netherlands/BackhuysPublishers, Leiden, Netherlands/CTA, Wageningen, Netherlands 


\section{International Journal of Science and Research (IJSR) \\ ISSN (Online): 2319-7064}

Index Copernicus Value (2013): 6.14 | Impact Factor (2014): 5.611

[2] Arora \& Mera, (2003), Management of water hyacinth biomass, applying the World Lake Vision to the LermaChapala basin

[3] Bartodziej \& Waymouth, 1995; Brendance et al,(2003), Water bird abundance and activity on water hyacinth and Egeriain the St-Marks river, Florida. Journal of Aquatic Plant Management

[4] Bicudo D., Fonseca B., Bini L., Crossetti L.,Bicudo C., \&Aranjo, T., (2007) Undesirable side effects of water hyacinth control in a shallow tropical reservoir, Fresh water biology

[5] Card, A., Whiting, D., Wilson, C., Reeder, J. (2009) OrganicFertilisers. Colorado Gardener Training Certificate.Colorado State University

[6] Das,A. \& Kalamdhad, S.,(2011),Evaluation of water hyacinth compost stability, using respirometric techniques, Department of Civil Engineering, Indian Institute of Technology Guwahati, India

[7] Dearl Sanders \&Johnson (2004) Biological Control of Common Salvinia in Louisiana,

[8] Divers, S.(1999) Notes on Compost teas. http://www.attra.org/attra-pub/PDF/compost-teanotes.pdf

[9] Ebel, Mathias et al.; Evangelou, MW; Schaeffer, A (2007). "Cyanide phytoremediation by water hyacinths (Eichhornia crassipes)". Chemosphere (Elsevier) 66 (5): 816-823.

[10] Gichuki, J., (2010), A journal on A native grass destroys Water hyacinth in Lake Victoria East Africa

[11] Gopal, B., (1987), Aquatic Plant Studies, Water Hyacinth, Elsevier Publishing, New York, USA.

[12] Gourab G. \&Soumen P., (2008) Studying the multiple usage of water hyacinth

[13] Greenfield B., Siemering G., Andrews J.,Rajan M, Andrews S.\& SpencerD.,(2007),Mechanical shredding of water hyacinth: Effects on water quality in the sacramento-san Joaquin Delta California, Estuaries and coasts

[14] Henrylito D., (2001), Water Hyacinth Ecological Value, Environmental

Impacts, http://www.gaiadiscovery.com/nature-

biodiversity/water-hyacinth- ecological- valueenvironmental-impacts.ht

[15] IFOAM, (2008).Definition of Organic Farming.http://www.ifoam.org/growing_organic/definit ions/doa/index.html.

[16] Jagadish H, Prajwal H, Malini B, Manoj V, Deepika D, Chaitra D.,( 2012)Vermicomposting of water hyacinth with poultry litter using rotary drum reactor

[17] Jafari N. (2010) Ecological and socio-economic utilization of water hyacinth (Eichhorniacrassipes) Department of Biology, Faculty of Basic Sciences, University of Mazandaran, Babolsar, Iran.

[18] Kelly, (2009); Anaerobic Digestion of harvested aquatic weeds, water hyacinth (EichhorniaCrasspes),Cabomba and Salvinia, Ecological EngineeringVolume36,issue10,October 2010

[19] Kothari C.R,(2004)Research Methodology; Methods and Techniques, second revised edition
[20] King C., (2012),Water hyacinth general information University of Florida, IFAS, Center for Aquatic Plantshttp://aquat1.ifas.ufl.edu/hyacin2.html

[21] Kiwango Y. \&Wolanski E., (2007) Global and planetary change, volume 57.

[22] Kirk, R. E. (1995). Experimental design. Procedures for the behavioral sciences (3rd ed.). Pacific Grove, CA: Brooks/Cole Publishing Co.

[23] Lata N.,\&Veenapani D (2011) Response of water hyacinth manure on growth attributes and yield in brassica Juncea

[24] Lu, J., Wu, J., Fu, Z.\& Zhu, L., (2007) Water hyacinth in China: A sustainability science based management framework, Environmental management

[25] LVEMP, (2004), Experiences and Lessons Learned from Interventions in the Lake Victoria basin: the Case of Lake Victoria Environmental Management Project, World Bank

[26] Martinez, M., \& Gomez, M., (2007) Integrated control of Eichhornia crassipes by using insects and plant pathogens in Mexico

[27] Mathew N., (2008) Environmental study and monitoring of undesirable chemical substances in fish/seafood. A proposal for Lake Victoria, Kenya

[28] Matai S, Bagchi D.(1980) Water hyacinth: a plant with prolific bioproductivity and photosynthesis

[29] Muyodi, Fredrick-Jones, Bugenyi, Fredrick, Hecky\& Robert, (2009) World Lake Conference, Wuhan, China.

[30] Mugenda \& Mugenda, (2003), Research Methodology; Methods and Techniques

[31] Misbahuddin M, Fariduddin A (2002 )Water hyacinth removes arsenic from arsenic-contaminated drinking water.

[32] Ogulande Y.,(2012) Notes on utilization of water hyacinth (Eichorrnia Crassipes) as a means of pollution control

[33] Omwoyo, O., (2012) Production of organic fertilizer from water hyacinth (Eichhornia crassipes [Mart.] Solms) for organic farming and conservation of ecosystem in Lake Victoria basin

[34] Ojeifo M, Ekokotu P, Olele N. \&Ekelemu J., (2012)A review of the utilisation of water hyacinth:alternative and sustainable control measures for a noxious weed

[35] Perna \& Burrows D., (2005) Improved dissolved oxygen status following removal of exotic weed mats in important fish habitat lagoons of the tropical Burdekin River floodplain, Marine pollution Bulletin, Australia

[36] Pinto-Coello \& Greco, (2012), Ecological and socioeconomic impacts of water hyacinth (Echhornia crasspes ): a review, Fresh water Biology

[37] Rodríguez-Gallego L.R., Mazzeo N., Gorga J., Meerhoff M., Clemente J., Kruk C., Lacerot G., García J. \&Quintans F. (2004) The effects of an artificial wetland dominated by free floating plants on the restoration of a subtropical, hypertrophic lake.

[38] Rocha-Ramirez, A., A. Ramirez-Rojas, R. ChavezLopez, \& J. Alcocer, (2007) Invertebrate assemblages associated with root masses of Eichhornia crassipes (Mart.) Solms-Laubach 1883 in the Alvarado Lagoonal 
System, Veracruz, Mexico. Aquatic Ecology 41:319333.

[39] Rommens W., Maes J., Dekeza N., Inghelbrecht P., Nhiwatiwa T., Holsters E., Ollevier F., Marshall B. \&Brendonck L. (2003) The impact of water hyacinth (Eichhornia crassipes) in a eutrophic subtropical impoundment (Lake Chivero, Zimbabwe) Water quality.

[40] Sanni, K., and Adesina, J., (2012) Response of water hyacinth manure on growth attributes and yields of Celosia argenteal (Lagos Spinach). Journal of Agricultural Technology

[41] Schippers R., (2002) African indigenous vegetables an overview of the cultivatedspecies. Chatham, UK. Natural Resources Institute /ACP-EU Technical Centre for Agricultural and rural Cooperation.

[42] Simbarashe G., Benard M. \& Precious, (2012)The Nutrient Content of Organic Liquid Fertilizers in Zimbabwe

[43] Uekermann \& Hill, (2001); www2.loot.co.za/index/htm/index3323.html

[44] Upadhya, Alka, \&Tripathi, (2007), Impact of Neochetinna Eichhornia on Biological Control of water hyacinth of Singanallar ponds, Coimbatore, Tamilnadu, India; India Journal of Natural Sciences 